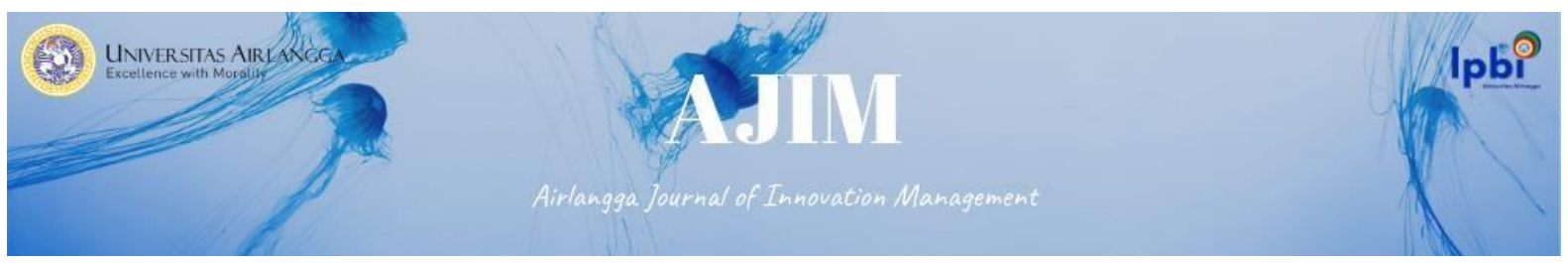

Vol. 2 No.2 Oktober 2021

e-ISSN: 2722-5062

DOI : 10.20473/ajim.v\%vi\%i.30866

\title{
THE EFFECT OF WORK ENVIRONMENT, WORK TRAINING AND PUNISHMENT ON WORK ACHIEVEMENT OF DPRD SECRETARIAT EMPLOYEES
}

\author{
Mulia Rosalia $^{a^{*}}$, Kelik Purwanto ${ }^{\mathrm{b}}$ Mayroza Wiska ${ }^{\mathrm{c}}$ \\ a,b,c Fakultas Hukum dan Ekonomi Bisnis, Universitas Dharmas Indonesia \\ *Corresponding e-mail : mulyarosalia14@gmail.com
}

\begin{abstract}
Human resources are a resource needed by an organization, because human resources are sources that play an active role in running of an organization and decision-making process. The existence of human resources in a company or government agency plays a very important role. By improving quality of human resources, it is expected that employees can work productively and professionally so that employee's work performance is expected to be more satisfactory according to required work standards. This study aims to determine the effect of work environment, job training and punishment on work performance of non-civil servant employees. The case study of this research is at DPRD Secretariat of Merangin Regency. The type of research used in this study is quantitative research, sample of this research is non-civil servant employees at DPRD Secretariat of Merangin Regency. This sampling uses nonprobability sampling. The tool used to collect data is in form of a questionnaire consisting of 40 questions, data is analyzed using Validity Test, Reliability Test, Multicollinearity Test, Normality Test, Heteroscedasticity Test, R2 Determination Coefficient Test, Multiple Multiple Regression Analysis Test, Partial Hypothesis Testing ( T-test), Simultaneous Hypothesis Testing (F-Test). The results of this study indicate that dependent variable work environment (X1), job training (X3) and punishment (X4) have a positive and significant effect on employee performance.
\end{abstract}

Keywords: Work Environment, Training, Punishment; and Work Performance.

\section{Introduction}

Human resources are one of resources needed by an organization, because human resources are something that plays an active role in the running of an organization and the process for making a decision. By increasing human resources by an agency, it will result in employees working productively and professionally so that employee performance will be satisfactory. One of the ways to measure productivity of human resource is by seeing their work performance. Work performance is a very important factor to support one's success both in 


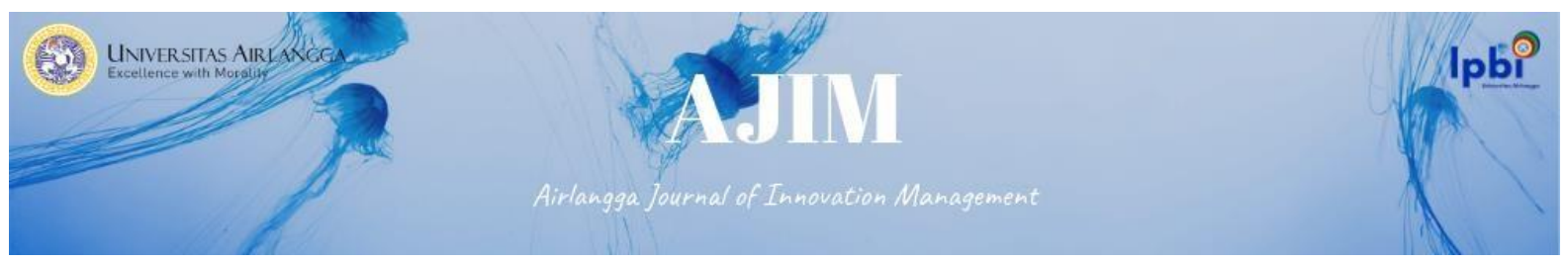

one's own capacity and as a member of an organization/institution. Work performance is the success that has been achieved by someone from his work behavior in carrying out a job.

There are some factors affect human resource work performance: they are work environment, training, and punishment. Work environment is all things related to employee activities in an agency. Every employee has the same right to get complete comfort and facilities at work. Work environment means a situation in which employees do work every day. There are times when every employee has the same right to get comfortable at work. Because if the employee feels comfortable with the job, the employee will do the job wholeheartedly without complaining (Muayanah, Haryono, 2018). Job training is all activities to obtain, improve and develop self-potential, productivity, attitude and work ethic at the level of skills and expertise according to the field and expertise of each employee. Punishment is a punishment given to employees who violate the rules or make mistakes that have been set in an agency. It should be given to employees who violate the rules through consideration very careful and the punishment given according to the mistakes they made. According to (Purnama, Ade Vici 2015).

The DPRD Secretariat of Merangin Regency is one of the offices that has many employees, with the majority of non-civil servants working. the number of employees resulted in the employee's work environment being rated less well due to the lack of space and employee work facilities which made employees lazy to work and made employees delay their work, employees felt bored while in the office and resulted in employees going home before work hours. The quality of the work environment in the Merangin Regency DPRD Secretariat can affect the work performance of non-civil servants at the Merangin Regency DPRD Secretariat because the lack of office facilities and space will result in employees feeling lazy to work. For non-civil servants at the DPRD Secretariat of Merangin Regency, a high level of work performance can provide special benefits for employees, such as increasing salaries, and making them more skilled and experienced in their field of work. In addition, a comfortable work environment can also affect a person's work performance, if someone feels a comfortable workplace then the work will be completed properly and work performance will increase rapidly.

Based on this description, the researcher considers it necessary to conduct further research on the effect of work environment variables, training and punishment on employee work performance to be able to complete the thesis with the title "The Influence of the Work Environment, Job Training and Punishment on the Work Performance of Non-PNS Employees at the DPRD Secretariat Merangin Regency in 2021"

\section{Literature Review}

\section{Resource Management}

Resource Management Experts Humans like H. Hadari Nawawi (2001:40), Saydam (2000:5), Dessler (2000:2), McKenna \& Here Beech (2001:1), Soeprihanto (1996:3), Nitisemito (1998:10), Moekijat (1996:2), Lateiner (1995:67-68) and others concluded that Human Resource Management is all activities carried out starting from activities planning, organizing, directing, coordinating, to controlling all values which is the power of man, for used for the benefit of human life.

\section{Work Environment}

The work environment is all things related to employee activities in an agency. Every employee has the same right to get complete comfort and facilities at work. Because when the employee feels 


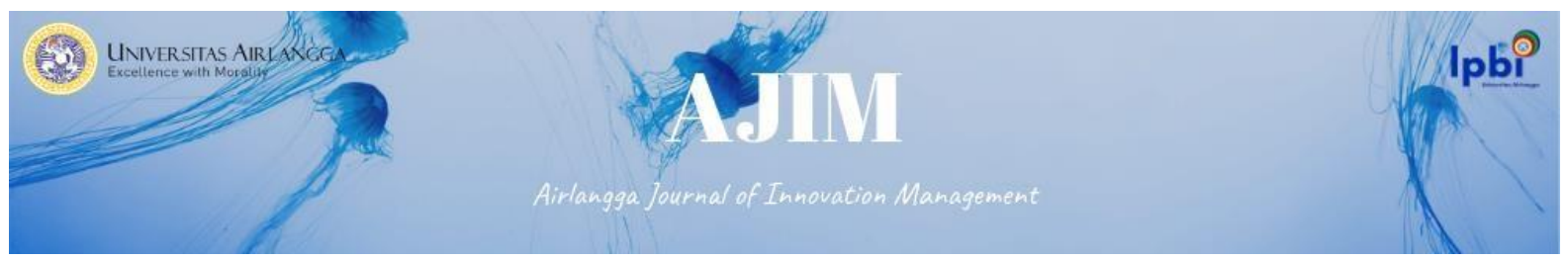

comfortable with the work he is doing, employee will carry out his work wholeheartedly without complaining. For example, there is not enough air conditioning in the work room, employees work less comfortable and cannot focus because of the heat caused by no air circulation coming in.

Sedarmayanti (2001) states that broadly speaking, types of work environments are divided into: into two, namely the physical work environment and non-physical work environment. The physical work environment is all physical conditions that exist in the workplace that can affect employees either directly or indirectly. The physical work environment can be shared into two categories, namely: (1) an environment that is directly related to employees, such as: work centers, chairs, tables and so on; (2) the intermediate environment or the general environment can also called the work environment that affects the human condition, for example: temperature, humidity, air circulation, lighting, noise, mechanical vibration, unpleasant odors, colors, etc. To be able to minimize the influence of the physical environment on employees, the first step is to: is to study humans, both about their physical and behavior, which then used as a basis for thinking about the appropriate physical environment.

\section{Training}

Job training is all activities to obtain, improve and develop self-potential, productivity, attitude and work ethic at the level of skills and expertise according to the field and expertise of each employee. According to Gomes (1995: 197), training is every effort to improve work performance in a particular job that is being his responsibility. Ideally, training should be designed to achieve organizational goals, while at the same time realize the goals of individual workers. Training is often thought of as the most common activities, workers will become more skilled and therefore more productive even though these benefits must be calculated with the time taken when workers are being trained. According to Manullang (2004:203), training is defined as a reward for company activities that designed to improve or enhance the knowledge, skills, and attitudes of employees in accordance with the needs of the company so that the employee concerned is more advanced in carry out certain tasks. Mangkunegara (2003:24) suggests that training is a long-term educational process short that uses systematic and organized procedures, non-managerial employees learn technical knowledge and skills within a limited purpose.

Meanwhile, according to Simamora (2006:273) suggests that training is a a process that involves acquiring skills, concepts, rules, or attitudes to improve workforce performance. The function of job training according to (Harding et al., 2018)

1. To ensure that the workforce does work in ways that are in accordance with the expectations of the organization/industry so that they are able to maintain consistent performance to achieve what they want to achieve.

2. To increase employee interest in a job and move employees to carry out work more effectively and achieve.

3. To be introduced to employees about the priorities, values, norms, procedures, and systems of an organization in general. So that skills can be improved through the training that is held.

\section{Punishment}

Punishment is a punishment given to employees who violate the rules or make mistakes that have been set in an agency, if the punishment is used effectively it can suppress employee behavior in the organization, in other words punishment (punishment) should be given to employees who violate the rules through consideration very careful and the punishment given according to the mistakes they made.

M. Ngalim in Purwanto, (2006: 186), Punishmet is suffering that given or caused intentionally or someone after an offense has occurred, crime or wrongdoing. of several the opinion above, punishment is a unpleasant act, which in the form of punishment or sanctions given to employees assigned to employees are aware when a violation occurs so as not to do it again. If reward is a positive form, then punishment is as a negative form, but if given correctly and wisely can be an employee incentive tool for improve its performance. The purpose of the method this is causing displeasure in someone so they don't make something evil. So, the punishment that done is to repair and educate for the better. 


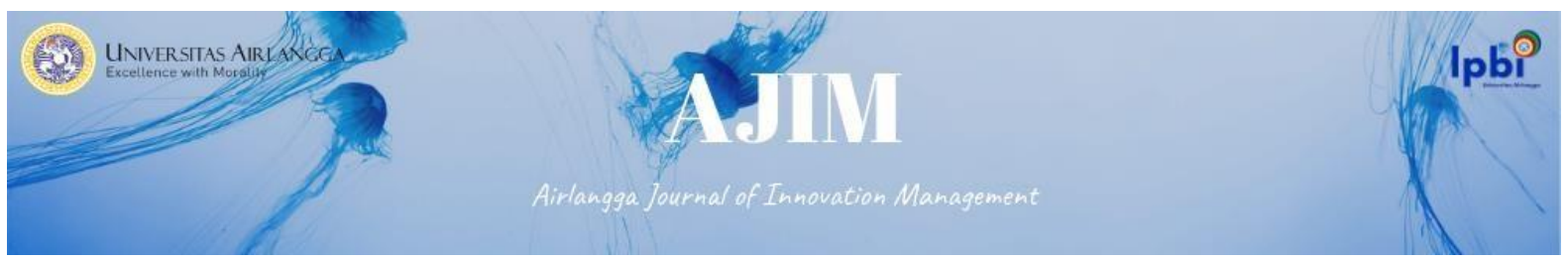

\section{Employee Work Performance}

Work performance is a very important factor to support one's success both in one's own capacity and as a member of an organization/institution. Work performance is the success that has been achieved by someone from his work behavior in carrying out a job. Information about the high and low work performance of an employee cannot be obtained simply by superiors, but employee performance is obtained through a long process, namely the process of evaluating employee performance.

According to (Rokhmawati \& Article, 2013) performance appraisal is a process in which organizations evaluate or assess employee performance. This activity can improve personnel decisions and provide feedback to employees about their work performance. Factors that affect employee performance are: a. Ability in a job, attitude and interest of an employee; $b$. The level of understanding of the role of a worker; c. Level of work motivation.

\section{Hypothesis}

Based on the main problems that have been stated previously, the authors draw tentative assumptions as follows; It is suspected that the work environment, job training, and punishment have a positive and significant effect on the work performance of non-civil servants at the Secretariat of the DPRD of Merangin Regency.

\section{Methods/Materials}

Quantitative research is data obtained through structured questions in the form of numbers whose nature can be calculated and measured for processing. While quantitative research is a method whose data are in the form of words, sentences or pictures. In this study, the researcher used a research design using quantitative data research and was assisted by data collection using a questionnaire (Prof. Dr. Sugiyono.2013)

The population is the entire object of research, so the total population in this study are all non-PNS employees of the DPRD Secretariat of Merangin Regency. The sample is part of the number of research objects owned by the population. The sampling technique is to use some objects from the population. Based on the information above, the sampling technique for this research is to use the population for some of the research samples, namely 97 non-civil servants at the DPRD Secretariat of Merangin Regency using the slovin formula

\section{Results and Discussion}

To test the validity and reliability of the instrument, the authors used SPSS analysis. Validity test is used to measure whether or not a questionnaire is valid. The questionnaire is said to be valid, if the statement in the questionnaire is able to reveal whether what will be measured is valid or not, the data is $\mathrm{r}$ arithmetic greater than rtable at a significant level of $5 \%$ or 0.05 . If the coefficient of rcount is greater than rtable, then the measuring instrument is valid.

In this study, the test was carried out with two sides with a significant level of 0.05 , with the following test criteria. The $r$-table value is 0.201 as seen from the $r$-table product moment correlation coefficient formula ( $\alpha ; n-3-1)$ significant value 0.05 with two-sided test and the number of $\mathrm{n}$ (respondents) is 97 $3-1=93$ respondents. The results of the validity analysis using SPSS version 16.0 can be seen from the table as follows: 


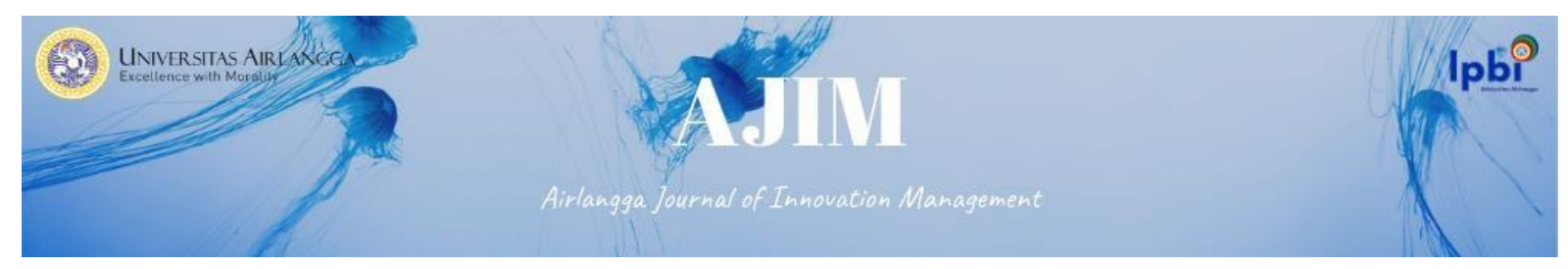

Tabel 4. 7

Variable Validity Test Results

\begin{tabular}{|c|c|c|c|}
\hline No & $\begin{array}{c}\text { r count } \\
\mathbf{n = 9 7}\end{array}$ & $\begin{array}{r}\mathbf{r} \text { table 5\% } \\
\mathbf{D f = N = 9 7}\end{array}$ & Criteria \\
\hline $\mathbf{1}$ & 0,579 & 0,201 & Valid \\
\hline $\mathbf{2}$ & 0,716 & 0,201 & Valid \\
\hline $\mathbf{3}$ & 0,584 & 0,201 & Valid \\
\hline $\mathbf{4}$ & 0,693 & 0,201 & Valid \\
\hline $\mathbf{5}$ & 0,618 & 0,201 & Valid \\
\hline $\mathbf{6}$ & 0,582 & 0,201 & Valid \\
\hline $\mathbf{7}$ & 0,671 & 0,201 & Valid \\
\hline $\mathbf{8}$ & 0,701 & 0,201 & Valid \\
\hline $\mathbf{9}$ & 0,743 & 0,201 & Valid \\
\hline $\mathbf{1 0}$ & 0,699 & 0,201 & \\
\hline
\end{tabular}

Source: Processed version 20 spss data

Based on the comparison between r-count and r-table where all t-count is greater than t-table 0.201 , it can be concluded that all items for the work environment variable (X1) are valid.

Tabel 4.8

Variable Validity Test Results

\begin{tabular}{|c|c|c|c|}
\hline No & $\begin{array}{c}\text { r count } \\
\mathbf{n = 9 7}\end{array}$ & $\begin{array}{c}\mathbf{r} \text { table 5\% } \\
\mathbf{d f = N = 9 7}\end{array}$ & criteria \\
\hline $\mathbf{1}$ & 0,708 & 0,201 & Valid \\
\hline $\mathbf{2}$ & 0,536 & 0,201 & Valid \\
\hline $\mathbf{3}$ & 0,644 & 0,201 & Valid \\
\hline $\mathbf{4}$ & 0,658 & 0,201 & Valid \\
\hline $\mathbf{5}$ & 0,775 & 0,201 & Valid \\
\hline $\mathbf{6}$ & 0,497 & 0,201 & Valid \\
\hline $\mathbf{7}$ & 0,775 & 0,201 & Valid \\
\hline $\mathbf{8}$ & 0,549 & 0,201 & Valid \\
\hline $\mathbf{9}$ & 0,662 & 0,201 & Valid \\
\hline $\mathbf{1 0}$ & 0,658 & 0,201 & Valid \\
\hline
\end{tabular}

Source: Processed version 20 spss data

Based on the comparison between $\mathrm{r}$-count and $\mathrm{r}$-table where all $\mathrm{t}$-count is greater than $\mathrm{t}$-table 0.201 , it can be concluded that all items for the job training variable (X2) are valid.

Table 4.9

Variable Validity Test Results

\begin{tabular}{|c|c|c|c|}
\hline No & r count $\mathbf{n = 9 7}$ & $\mathbf{r}$ table 5\% $\mathbf{~ d f = N = 9 7}$ & criteria \\
\hline $\mathbf{1}$ & 0,597 & 0,201 & Valid \\
\hline $\mathbf{2}$ & 0,566 & 0,201 & Valid \\
\hline $\mathbf{3}$ & 0,647 & 0,201 & Valid \\
\hline $\mathbf{4}$ & 0,580 & 0,201 & Valid \\
\hline $\mathbf{5}$ & 0,562 & 0,201 & Valid \\
\hline $\mathbf{6}$ & 0,481 & 0,201 & Valid \\
\hline $\mathbf{7}$ & 0,719 & 0,201 & Valid \\
\hline $\mathbf{8}$ & 0,645 & 0,201 & Valid \\
\hline $\mathbf{9}$ & 0,649 & 0,201 & Valid \\
\hline $\mathbf{1 0}$ & 0,687 & 0,201 & Valid \\
\hline
\end{tabular}

Source: Processed version 20 spss data

Based on the comparison between r-count and r-table where all t-counts are greater than t-table 0.201 , it can be concluded that all questions for the punishment variable (X3) are valid. 


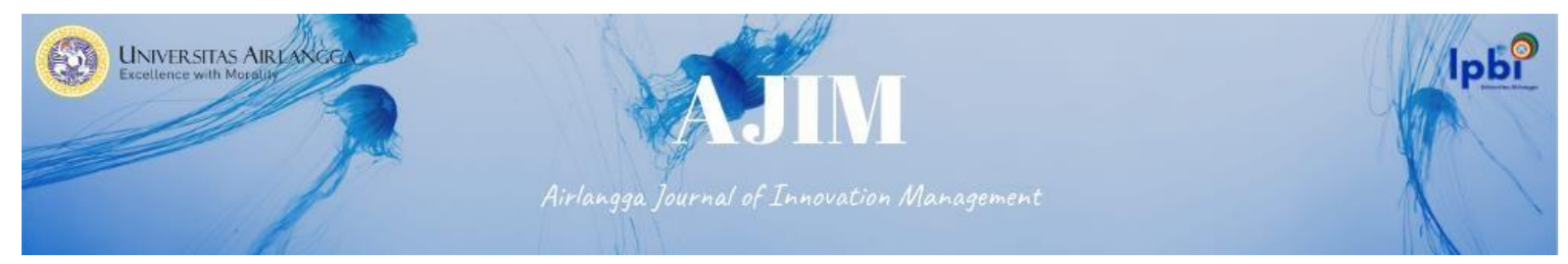

Table 4.10

Variable Validity Test Results

\begin{tabular}{|c|c|c|c|}
\hline No & $\begin{array}{c}\mathbf{r} \text { count } \\
\mathbf{n = 9 7}\end{array}$ & $\begin{array}{r}\mathbf{r} \text { table 5\% } \\
\mathbf{d f = N = 9 7}\end{array}$ & criteria \\
\hline $\mathbf{1}$ & 0,404 & 0,201 & Valid \\
\hline $\mathbf{2}$ & 0,429 & 0,201 & Valid \\
\hline $\mathbf{3}$ & 0,443 & 0,201 & Valid \\
\hline $\mathbf{4}$ & 0,427 & 0,201 & Valid \\
\hline $\mathbf{5}$ & 0,361 & 0,201 & Valid \\
\hline $\mathbf{6}$ & 0,454 & 0,201 & Valid \\
\hline $\mathbf{7}$ & 0,294 & 0,201 & Valid \\
\hline $\mathbf{8}$ & 0,431 & 0,201 & Valid \\
\hline $\mathbf{9}$ & 0,781 & 0,201 & Valid \\
\hline $\mathbf{1 0}$ & 0,418 & 0,201 & Valid \\
\hline
\end{tabular}

Source: Processed version 20 spss data

Based on the comparison between $\mathrm{r}$-count and $\mathrm{r}$-table where all $\mathrm{t}$-count is greater than $\mathrm{t}$-table 0.201 , it can be concluded that all items for the work achievement variable (Y) are valid..

\section{Reliability}

Reliability aims to determine the extent to which the measurement results remain consistent, if two or more measurements are made of the same symptom using the same measuring instrument, the technique or formula used to determine whether a research instrument is reliable or not. Reliability is an index that shows the extent to which a measuring instrument is trusted or reliable. As for how to find out how much the level of reliability of an instrument can be tested on each data from the related variables. A construct or variable is said to be reliable if the Cronbach Alpha value $>0.60$ (Star Nerpati in Imam Ghozali, 2012) The criteria for a research instrument are said to be reliable using this technique, if the reliability coefficient $(\mathrm{r} 11)>0.60$. The formula used to test the reliability in this study is to use the formula for the coefficient alpha $(\alpha)$ from Crobanch, namely: The following are the criteria for testing reliability measurements:

1) If the value of Cronbanch alpha ( 111$)>0.60$ then the variable item is declared reliable.

2) If the value of Cronbanch alpha $(\mathrm{r} 11)<0.60$ then the variable item is declared unreliable.

The following will present the results of the reliability test using SPSS version 16.0 which can be seen in the following table:

Table 4.11

Work Environment Variable Reliability (X1), Job Training (X2), Punishment (X3) and Work Performance (Y)

\begin{tabular}{|c|c|c|c|c|}
\hline \multirow[b]{2}{*}{ Variable } & \multicolumn{2}{|c|}{$\mathrm{N}=97$} & \multirow[b]{2}{*}{$\begin{array}{l}\text { Rule of } \\
\text { thumb }\end{array}$} & \multirow[b]{2}{*}{ Decision } \\
\hline & $\begin{array}{l}\text { Number of } \\
\text { question } \\
\text { items }\end{array}$ & $\begin{array}{l}\text { Cronbac } \\
\text { h alpha }\end{array}$ & & \\
\hline Work environment (X1) & 10 & 0,665 & 0,6 & Reliable \\
\hline Work training (X2) & 10 & 0,615 & 0,6 & Reliable \\
\hline Punishment (X3) & 10 & 0,710 & 0,6 & Reliable \\
\hline Work performance $(\mathrm{Y})$ & 10 & 0,708 & 0,6 & Reliable \\
\hline
\end{tabular}

Source: Processed version 20 spss data

From table 4.11 above, it can be seen that all instruments based on reliability analysis above research variables show that the value (Cronbanch's alpha) for all variables is 0.6 for that all variables can be said to be reliable or reliable. 


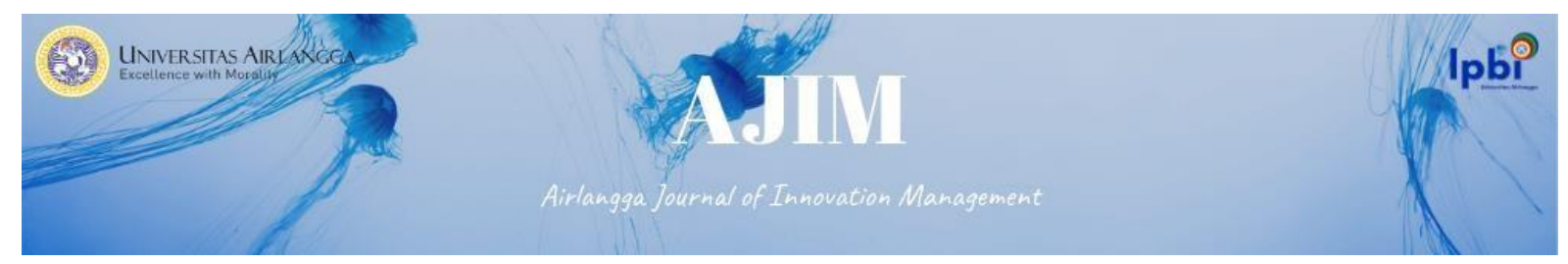

Table 4.15

Multiple Regression Analysis Results

\begin{tabular}{|c|c|c|c|c|c|}
\hline \multicolumn{6}{|c|}{ Coefficients $^{\mathrm{a}}$} \\
\hline \multirow[b]{2}{*}{ Modle } & \multicolumn{2}{|c|}{$\begin{array}{l}\text { Unstandardized } \\
\text { Coefficients }\end{array}$} & \multirow{2}{*}{\begin{tabular}{|l|} 
Standard \\
ized \\
Coefficients \\
Beta \\
\end{tabular}} & \multirow[b]{2}{*}{$\mathrm{T}$} & \multirow[b]{2}{*}{$\mathrm{Si}$} \\
\hline & B & $\begin{array}{l}\text { Std. } \\
\text { Error }\end{array}$ & & & \\
\hline (Constant) & 5,595 & 12,293 & & 1,260 & 211 \\
\hline Work environment & ,608 &, 078 & 620 & 7,792 & 000 \\
\hline Work training & , 156 &, 076 & , 158 & 2,045 &, 044 \\
\hline Punishment & ,111 &, 085 & 097 & 1,306 & , 195 \\
\hline
\end{tabular}

Source: Processed version 20 spss data

Based on table 4.15 above, it can be seen that the regression equation is: $\mathrm{Y}=5.595+0.608 \mathrm{X} 1+0.156 \mathrm{X} 2$ $+0.111 \mathrm{X} 3+\mathrm{e}$. Based on these equations it can be interpreted as follows:

1. The constant of 5.595 means that if the work environment, job training and punishment do not exist, then work performance remains at a constant of 5.595

2. If the work environment is increased by one unit, assuming job training and punishment are ignored, it will result in an increase in work performance of 0.608

3. If the training is increased by one unit, assuming the work environment and punishment are ignored, it will result in an increase in work performance of 0.156

4. If punishment is increased by one unit, assuming the work environment and training are ignored, it will result in an increase in work performance of 0.111

Table 4.19

Partial Hypothesis Testing (T Test)

\begin{tabular}{|c|c|c|c|c|c|c|c|c|}
\hline \multirow{2}{*}{\multicolumn{2}{|c|}{ Modle }} & \multicolumn{2}{|c|}{$\begin{array}{l}\text { Unstandardized } \\
\text { Coefficients }\end{array}$} & \multirow{2}{*}{$\begin{array}{c}\text { Standardized } \\
\text { Coefficients } \\
\text { Beta }\end{array}$} & \multirow[t]{2}{*}{$\mathrm{T}$} & \multirow[t]{2}{*}{ Sig. } & \multicolumn{2}{|c|}{$\begin{array}{c}\text { Collinearity } \\
\text { Statistics }\end{array}$} \\
\hline & & B & $\begin{array}{l}\text { Std. } \\
\text { Error }\end{array}$ & & & & $\begin{array}{c}\text { Tolera } \\
\text { nce }\end{array}$ & VIF \\
\hline \multirow{4}{*}{1} & Constant) & 5,595 & 4,440 & & 1,260 & ,211 & & \\
\hline & Work environment & 608 & ,078 & ,620 & 7,792 &, 000 & ,765 & 1,307 \\
\hline & Work training &, 156 & ,076 &, 158 & 2,045 &, 044 &, 813 & 1,230 \\
\hline & Punishment &, 111 & , 085 & ,097 & 1,306 & , 195 & ,872 & 1,146 \\
\hline
\end{tabular}

Source: Processed version 20 spss data

From table 4.19 above it can be interpreted as follows:

1. Effect of Work Environment (X1) on Work Performance (Y).

From table 4.19 above, it can be seen that the t-count is 7.792 and the $t$-table is 1.661 , where the $t-$ count is greater than the t-table $(7.792>1.661)$, so the work environment affects work performance. And the significance value $(0.000<0.05)$, then the work environment variable has a significant effect on work performance. it can be obtained that $\mathrm{H} 0$ is rejected and $\mathrm{H} 1$ is accepted, meaning that the work environment (X1) has a positive and significant effect on work performance (Y).

2. The Effect of Job Training (X2) on Job Performance (Y)

From table 4.19 above, it can be seen that the $\mathrm{t}$-count is 2.045 and the $\mathrm{t}$-table is 1.661 , where the $\mathrm{t}$ count is greater than the t-table $(2.045>1.661)$. This shows that the training variable has an effect on the work performance variable. And a significant level greater than alpha $(0.044<0.05)$ then it 


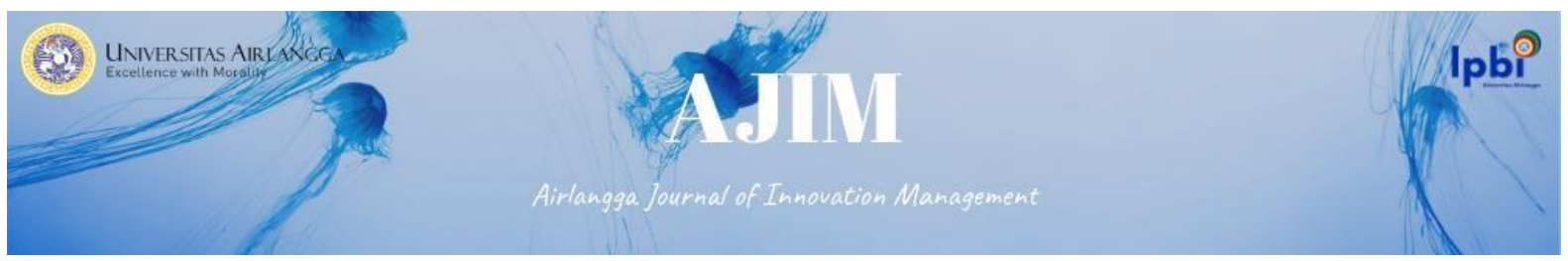

can be obtained that $\mathrm{H} 0$ is rejected and $\mathrm{H} 2$ is accepted, meaning that job training (X2) has a positive and significant effect on work performance (Y).

3. The Effect of Punishment (X3) on Work Performance (Y)

From table 4.19 above, it can be seen that the $\mathrm{t}$-count is 1.306 and the $\mathrm{t}$-table is 1.661 , where the $\mathrm{t}$ count is greater than the t-table $(1,306<1.661)$. This shows that the punishment variable has a positive effect on the work performance variable. And the significant level is greater than alpha $(195>0.05)$ then it can be obtained that $\mathrm{H} 0$ is rejected and $\mathrm{H} 3$ is accepted, meaning that punishment (X3) has no positive and insignificant effect on purchasing decisions (Y)

Table 4.20

Hypothesis Testing Together (F Test)

ANOVA $^{\mathrm{a}}$

\begin{tabular}{|l|l|c|c|c|c|}
\hline \multicolumn{1}{|c|}{ Modle } & \multicolumn{1}{|c|}{$\begin{array}{c}\text { Sum of } \\
\text { Squares }\end{array}$} & Df & $\begin{array}{c}\text { Mean } \\
\text { Square }\end{array}$ & F & Sig. \\
\hline Regression & 1030,989 & 3 & 343,663 & 37,800 &, $000^{\mathrm{b}}$ \\
Residual & 845,527 & 93 & 9,092 & & \\
Total & 1876,515 & 97 & & & \\
\hline
\end{tabular}

Source: Processed version 20 spss data

From table 4.20 above, it can be seen that this test was carried out by comparing the $\mathrm{F}$ value with $F$ because the $F$ value was greater than the $F$ value $(37.800>3.09)$. F value 37,800 with a significant level $(0.000<0.05)$. Then it is obtained that Ho is rejected and $\mathrm{H} 4$ is accepted, which means that this is done jointly between the work environment, job training and punishment and has a significant and significant effect on work performance.

Table 4.21

Research Hypothesis Testing Results

\begin{tabular}{|c|l|c|c|l|}
\hline Hypothesis & \multicolumn{1}{|c|}{ Statement } & Significant & Comparison & Decision \\
\hline H1 & $\begin{array}{l}\text { It is suspected that the work environment } \\
\text { has a positive effect on work performance }\end{array}$ & 0,000 & 0,05 & Accepted \\
\hline H2 & $\begin{array}{l}\text { It is suspected that job training has a } \\
\text { positive effect on purchasing decisions }\end{array}$ & 0,044 & 0,05 & Rejected \\
\hline H3 & $\begin{array}{l}\text { It is suspected that punishment has a } \\
\text { positive effect on work performance }\end{array}$ & 0,195 & 0,05 & Rejected \\
\hline H4 & $\begin{array}{l}\text { It is suspected that the work environment, } \\
\text { job training, and punishment have a } \\
\text { positive effect on work performance }\end{array}$ & 0,000 & 0,05 & Accepted \\
\hline
\end{tabular}

Source: Processed version 20 spss data

\section{Determination Test (R2)}

Table 4.22

Determination Test Results Model Summary

\begin{tabular}{|l|r|r|r|r|}
\hline Modle & $\mathrm{R}$ & $\begin{array}{c}\mathrm{R} \\
\text { Square }\end{array}$ & \multicolumn{1}{|c|}{$\begin{array}{c}\text { Adjusted R } \\
\text { Square }\end{array}$} & \multicolumn{1}{|c|}{$\begin{array}{c}\text { Std. Error of the } \\
\text { Estimate }\end{array}$} \\
\hline 1 &, $741^{\mathrm{a}}$ &, 549 &, 535 & 3,015 \\
\hline
\end{tabular}

Source: Processed version 20 spss data 


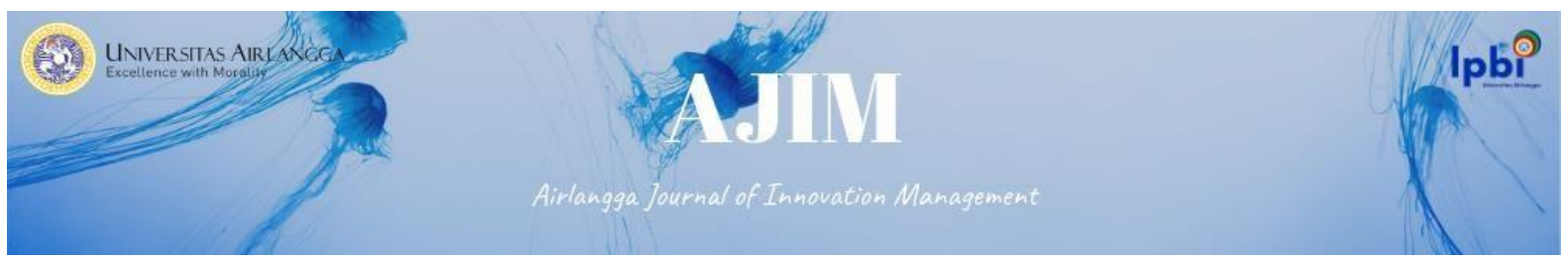

Based on table 4.22 above, R Square number is 0.549 , this shows that contribution of work environment variables, job training and punishment to work performance. of 0.549 . which means that effect of the training variable on job performance is $54.9 \%$, while $55.1 \%$ is influenced by other factors.

Analysis of the Relationship of Work Environment Variables to Work Performance

The analysis of work environment variable partially has a significant effect on work performance of non-civil servants at the DPRD Secretariat of Merangin Regency. From table 4.19 above, it can be seen that $\mathrm{t}$-count is 9.792 and the $\mathrm{t}$-table is 1.661 , where $\mathrm{t}$-count is greater than the $\mathrm{t}$-table $(9.792>$ $1.661)$, so work environment affects work performance. And the significance value $(0.000<0.05)$, then the work environment variable has a significant effect on work performance. it can be obtained that $\mathrm{H} 0$ is rejected and $\mathrm{H} 1$ is accepted, meaning that the work environment (X1) has a positive and significant effect on purchasing decisions (Y).

\section{Analysis of the Correlation of Job Training Variables on Job Performance}

Partial analysis of job training variables has no significant effect on work performance of noncivil servants at DPRD Secretariat of Merangin Regency. From table 4.19 above, it can be seen that tcount is 2.045 and $\mathrm{t}$-table is 1.661 where $\mathrm{t}$-count is greater than $\mathrm{t}$-table $(2.045>1.661)$. This shows that training variable has an effect on work performance variable. And a significant level greater than alpha $(0.044<0.05)$ then it can be obtained that $\mathrm{H} 0$ is rejected and $\mathrm{H} 2$ is accepted, meaning that job training (X2) has a positive effect and has no significant effect on work performance (Y).

Analysis of the Correlation of Variable Punishment on Work Performance.

The punishment variable partially has no significant effect on work performance of non-civil servants at DPRD Secretariat of Merangin Regency. From table 4.19 above, it can be seen that the tcount is 2.469 and t-table is 1.661 where $\mathrm{t}$-count is greater than t-table $(1,306<1.661)$ this shows that punishment variable has a positive effect on work performance variable. And level is significantly greater than alpha $(0.195>0.05)$ then it can be obtained that $\mathrm{H} 0$ is rejected and $\mathrm{H} 3$ is accepted, meaning that punishment (X3) is positive and has no significant effect on purchasing decisions (Y).

\section{Analysis of the Relationship between Work Environment Variables, Job Training and}

\section{Punishment on Achievement}

From table 4.20 above, it can be seen that this test was carried out by comparing $\mathrm{F}$ value with $\mathrm{F}$ because $\mathrm{F}$ value was greater than $\mathrm{F}$ value $(37.800>3.09)$. F value 37,800 with a significant level $(0.000<0.05)$. Then it is obtained that Ho is rejected and $\mathrm{H} 4$ is accepted, which means that this is done jointly between work environment, job training and punishment has a significant effect on work performance.

\section{Conclusion}

Based on results of research that has been done regarding effect of work environment, job training, and punishment on work performance of non-civil servants at DPRD Secretariat of Merangin Regency. So conclusions that can be drawn are as follows: The variables of work environment, job training, and punishment have a positive and significant effect on work performance of non-civil servants at DPRD Secretariat of Merangin Regency. Because all employees at Merangin Regency DPRD Secretariat are very friendly, relationship between employees is very harmonious, employees comply with applicable rules and regulations and employees at Merangin Regency DPRD Secretariat have specific abilities, skills, knowledge and behaviors related to work, so that they can encourage they can work better and result in an increase in employee performance.

\section{References}

Alex S Nitisemito, Personnel Management, Edition Four, Jakarta, Ghalia Indonesia, 1998.

Alfreed R. Lateiner, Techniques for Leading Employees and Workers, (In collaboration with TELEVINE. Translated by Imam Soedjono), Brilliant, Jakarta, 1995. 


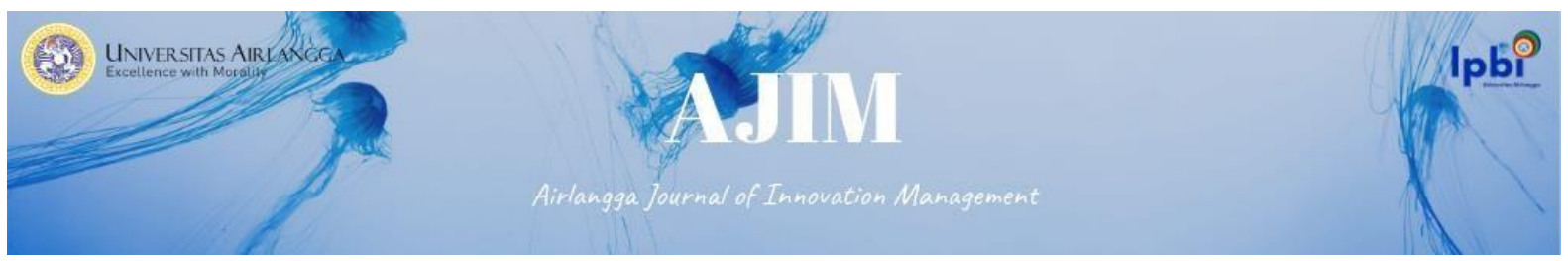

Eugene Mc Kenna and Nic Beech, Management Human Resources (Original Title The Essence Of Human Resources Management), Translated By Toto Budi Santoso, Andi and Pearson Publishers Education Asia Pte, Ltd, 2001.

Gary Dessler, Personnel Management, Translation, Erlangga, Jakarta 1986.

Gomes, Faustino Cardoso DR. 1995. Human Resource Management. Bandung :Rosdakarya Youth.

Gouzali Saydam, BC, TT, Resource Management Human Resources Management): A Micro Approach (In Q\&A), Djambatan, Jakarta, 2000.

Harding, D., Kadiyono, A. L., Hidayat, Y., \& Yuniarti, N. (2018). Human resource training and development asan answer toaec challenge. Journal of Science And Professional Psychology, 2(2), 185-192.

H. Hadari Nawawi, Resource Management Human For Competitive Business, UGM Press Publisher, Yogyakarta, 2001.

John Soeprihanto, Personnel Management, Yogyakarta, Faculty Publishing Agency Gajah Mada University Economics, 1996

Mangkunegara, AA. King Anwar. 2003. Human Resource Management. Bandung :Rosdakarya Youth. Manullang, M. 2004. Human Resource Management. Yogyakarta : BBPE.

Moekijat, Personnel Management, 5th Edition, Bandung, Alumni, 1996.

Muayanah, Haryono, \& W. (2018). The influence of the working environment on work performance in the Ketapang mining and energy department. 20(1), 31-39.

Purnama, Ade Vici. 2015. Thesis Journal of the Effect of Reward and Punishment on Employee Performance at Pt. Indonesian Railways Persero Daop 8 Surabaya

Purwanto.2007. Social Research Instruments and Education. Yogyakarta : Libraries Learn.

Rokhmawati, P., \& Article, I. (2013). Journal of Management Dynamics ANALYSIS OF EMPLOYEE ACHIEVEMENT ASSESSMENT. Jdm, 4(1), 23-29. http://journal.unnes.ac.id/nju/index.php/jdm

Sedarmayanti. (2001). Human resources and work productivity. Bandung: Forward Mandar. Simamora, Henry. 2004. Human Resource Management. Yogyakarta: STIE YKPN.

Sugiyono.2013. Qualitative Quantitative Research Methods and R\&D. Bandung: Alphabetal

Sutrisno. (2014). Journal of the effect of training on employee performance at the Rokan Hulu district inspectorate. Journal of the Effect of Training on Employee Work Performance at the Rokan Hulu Regency Inspectorate, 151.

Tanjung, D. H. (2015). The Effect Of Work Discipline And Work Motivation On Employee Achievement At The Social And Manpower Department Of Medan City (Vol. 15, Issue 01). 